\title{
The Running Speed Relation and the Power of Leg Muscle With Result of Conventional Style on Students
}

\author{
D. Fadel Muhammad ${ }^{1 *}$, Madri $\mathbf{M}^{1}$, Damrah $^{1}$, Lusi Angelia ${ }^{1}$ \\ ${ }^{1}$ Sport Education Program, Faculty of Sport Science, Universitas Negeri Padang, Indonesia \\ *Corresponding author. Email: fadelmuhammad714@yahoo.com
}

\begin{abstract}
This study aims to determine the relationship between running speed and explosive strength of leg muscles with the results of long jumps of students in class V and VI of SD Negeri 1 Sungai Salak, Indragiri Hilir Regency. The population of this study was 36 people. The sampling technique was purposive sampling. Data collection techniques used were tests and measurements for running speed tests, tests of leg muscle explosive power with Standing Broard Jump, and tests of the results of long jump abilities. The test results and measurements were then analyzed by SPSS 16.00 data processing techniques. Based on the results of the study show that: (1) There is a significant relationship between running speed and squat style long jump ability of 0.117 , (2) There is a significant relationship between leg muscle explosive power and squat style long jump ability of 0.318 , (3) a significant relationship between running speed and leg muscle explosive power to squat style long jump ability is 0.373 . The research conclusions there is a relationship between running speed, leg muscle power to the squat style long jump ability of class V and VI Sungai Salak Public Elementary School 1 Indragiri Hilir Regency.
\end{abstract}

Keywords: speed, leg muscle explosive power, long jump

\section{INTRODUCTION}

Athletics is one of the oldest sports that has existed and been carried out by humans since ancient times until now [1]. It can even be said that since the existence of humans on this earth, athletics has existed and been carried out by humans. That is because every movement in athletics such as walking, running, jumping and throwing is a manifestation of basic movements in everyday human life.

Jumping is one part of athletic exercise. In athletic sports there are several types of jump numbers, namely long jump, infectious jump or triple jump, high jump and pole jump. The four types of jump numbers are always contested in national, regional or international championships [2].

To produce the maximum leap, it requires physical conditions including leg muscle power and abdominal muscle strength, speed, agility balance and motion coordination have a large role for the results of a far leap which means that without the physical conditions above it cannot be done well.

The purpose of this study was to determine the relationship: to find out the relationship between running speed and the long jump ability of students in Class V and VI of SD Negeri 01 Sungai Salak Indragiri Hilir Regency, to determine the relationship between leg muscle explosive power and long jump ability of Class V and VI students at SD Negeri 01 Sungai Salak, Indragiri Hilir Regency.

\section{METHOD}

This research is a type of quantitative research. The variable of this study consists of independent variables and dependent variables. The independent variable $(\mathrm{X})$ in this study is the running speed and leg muscle strength while the dependent variable (Y) in this study is the result of the long jump. The place of research was conducted at Sungai Salak Elementary School 1 in Indragiri Hilir Regency. The sample used in this study was purposive sampling to choose 36 students. This study was conducted in 4 meetings. The data collection technique used in this study was a test. The data analysis technique used in this study is the analysis of test data using the formula [3]) and then scores will be obtained with the scale used, namely the gutman scale, then the score will be calculated into a percentage [4]. Then the percentage score from the test results will be categorized [5]. Then using prerequisite test data analysis techniques, and hypothesis testing.

\section{RESULTS AND DISCUSSION}

\subsection{Results \\ 3.1.1 Description of Research Data}

The variables in this study were speed, leg muscle explosive power with the result of the class Vlong jump and VI students of SD Negeri 1 Sungai Salak Elementary School in Indragiri Hilir Regency: 
Table 1. Description of Research Data.

\begin{tabular}{lccccc}
\hline Variabel & N & Mean & Std.dev & Min & Mak \\
\hline Speed & 36 & 4.23 & 0.28 & 3.59 & 4.81 \\
Explosive & 36 & 1.68 & 0.22 & 1.2 & 1.92 \\
$\begin{array}{l}\text { Power of } \\
\text { Leg }\end{array}$ & & & & & \\
$\begin{array}{l}\text { Muscles } \\
\begin{array}{l}\text { Long Jump } \\
\text { Results }\end{array}\end{array}$ & 36 & 2.67 & 0.58 & 1.3 & 3.9 \\
\hline Clearly deriptively & & & & & \\
\hline
\end{tabular}

Clearly descriptively can be presented as follows:

\subsubsection{Speed}

Descriptive analysis of the speed of the respondent's research, obtained a mean count $($ mean $)=4.23$, standard deviation $=0.28$, minimum value $=3.59$ and maximum $=$ 4.81. Furthermore, the frequency distribution of research data can be presented in the following table:

Table 2. Speed Data Frequency Distribution.

\begin{tabular}{ccc}
\hline $\begin{array}{c}\text { Interval } \\
\text { Class }\end{array}$ & $\begin{array}{c}\text { Absolutely } \\
\text { Frequency }\end{array}$ & $\begin{array}{c}\text { Relative Relative } \\
(\boldsymbol{\%})\end{array}$ \\
\hline $3.59-3.83$ & 3 & 8.33 \\
$3.84-4.08$ & 8 & 22.22 \\
$4.09-4.33$ & 13 & 36.11 \\
$4.34-4.58$ & 6 & 16.67 \\
$4.59-4.83$ & 6 & 16.67 \\
$\sum$ & 36 & 100 \\
\hline
\end{tabular}

Based on the table above, the speed of 36 samples of students in class V and VI of SD Negeri 1 Sungai Salak in Indragiri Hilir Regency was 3 respondents in the interval class $3.59-3.83,8$ respondents were in the interval class $3.84-4.08,13$ people respondents were in the interval class 4.09-4.33, 6 respondents were in the interval class 4.344.58 and 6 respondents were in the interval class 4.594.83 .

\subsubsection{Explosive Power of the Leg Muscles}

Descriptive analysis of explosive limb muscle power of the respondent's research, obtained a mean count (mean) $=1,678$, standard deviation $=0.22$, minimum value $=1.20$ and maximum $=1.92$. Furthermore, the frequency distribution of research data can be presented in the following table:

Table 3. Data Frequency Distribution of leg muscle explosive power

\begin{tabular}{ccc}
$\begin{array}{c}\text { Interval } \\
\text { Class }\end{array}$ & $\begin{array}{c}\text { Absolute } \\
\text { Frequency }\end{array}$ & $\begin{array}{c}\text { Relative } \\
\text { Frequency }(\%)\end{array}$ \\
$1.20-1.34$ & 4 & 11.11 \\
$1.35-1.49$ & 3 & 8.33 \\
$1.50-1.64$ & 4 & 11.11 \\
$1.65-1.79$ & 11 & 30.56 \\
$1.80-1.94$ & 14 & 38.89 \\
$\sum$ & 36 & 100 \\
\hline
\end{tabular}

Based on the table above, the explosive muscle power of 36 samples of students in the fifth and sixth grade of SD Negeri 1 Sungai Salak in Indragiri Hilir District was 4 respondents in the interval class $1.20-1.34,3$ respondents were in the interval class $1.35-1.49,4$ respondents were in the interval class $1.50-1.64,11$ respondents were in the interval class $1.65-1.79$ and 14 respondents were in the interval class 1.80-1.94.

\subsubsection{Long Jump Results}

Descriptive analysis of the results of long jump respondents shows that mean $=2.67$, standard deviation $=$ 0.58 , minimum value $=1.30$ and maximum $=3.90$. Furthermore, the frequency distribution of research data can be presented in the following table:

Tabel 4.Frequency Distribution of Long Jump Data.

\begin{tabular}{ccc}
\hline $\begin{array}{c}\text { Interval } \\
\text { Class }\end{array}$ & $\begin{array}{c}\text { Absolutely } \\
\text { Frequency }\end{array}$ & $\begin{array}{c}\text { Relative } \\
\text { Relative (\%) }\end{array}$ \\
\hline $1.30-1.82$ & 4 & 11.11 \\
$1.83-2.35$ & 8 & 22.22 \\
$2.36-2.88$ & 8 & 22.22 \\
$2.89-3.41$ & 14 & 38.89 \\
$3.42-3.94$ & 2 & 5.56 \\
$\sum$ & 36 & 100 \\
\hline
\end{tabular}

Based on the table above, it can be seen that the results of long jumps of 36 samples of students in grade V and VI of SD Negeri 1 Sungai Salak in Indragiri Hilir Regency, there were 4 respondents in interval classes $1.30-1.82,8$ respondents were in interval classes 1.83-2.35, 8 respondents were in the interval class 2.36-2.88, 14 respondents were in the interval class 2.89-3.41 and 2 respondents were in the interval 3.42-3.94.

\section{DISCUSSION}

Data processing and analysis were carried out to know the relationship of speed (X1), leg muscle explosive power (X2) and the long jump (Y). The statistical test used was product moment correlation analysis and multiple correlation at $0.05 \alpha$ significance level. The results of the analysis show that the speed, explosive power of the leg muscles has a significant relationship with the results of the long jump. Obviously it will be presented as follows:

4.1 There is a Significant Relationship of Speed (X1) with Long Jump Results (Y) of Class V and VI Students of SD Negeri 1 Sungai Salak, Indragiri Hilir Regency.

The results of the analysis show that speed (X1) has a significant relationship with the results of the long jump. The results of the product moment correlation analysis, the research data can be read that the relationship (correlation) speed with the results of the long jump is $0.343>$ rtab 0.329 , meaning that the relationship is strong and in the same direction. With Thit 2.129> Ttab 1.697. Thus the proposed work hypothesis (Ha) can be accepted. Furthermore, the determination of the results of data analysis (r2) is obtained at 0.117 . This means that speed as an independent variable can contribute $11.7 \%$ to the dependent variable, which is the result of the long jump. 
There is a Significant Relation of Explosive Power of Leg Muscles (X2) with Long Jump Results (Y) of Class V and VI Students of SD Negeri 1 Sungai Salak, Indragiri Hilir Regency.

The results of the analysis show that the explosive power of the leg muscles (X2) has significant relationship with the results of the long jump. This is consistent with the research conducted by the results of product moment correlation analysis, the research data can be read that the relationship (correlation) leg muscle explosive power with the long jump results is $0.564>$ rtab 0.329 , meaning the relationship of limb muscle explosive power is strong and unidirectional. With Thit 3.982> Ttab 1.697 Thus the proposed work hypothesis (Ha) can be accepted. Furthermore, the determination of the results of data analysis ( $\mathrm{r} 2$ ) is obtained at 0.318 . This means that the explosive power of leg muscles as independent variables can contribute $31.8 \%$ to the dependent variable, which is the result of the long jump. While the rest explained by other variables The results of the analysis can be seen in the appendix.

4.3 There is a Significant Relationship of Speed (X1) and Explosive Power of Leg Muscles (X2) Together with Long Jump Results (Y) of Class V and VI Students of SD Negeri 1 Sungai Salak Indragiri Hilir Regency.

The results of the analysis together $(\mathrm{X} 1,2)$ show that, the velocity together with the explosive power of the leg muscles has a significant relationship with the results of the long jump. The results of multiple correlation analysis, research data can be read that the relationship (correlation) velocity, leg muscle explosive power with the long jump results is $0.611>$ rtab 0.329 , meaning that together the relationship of speed, leg muscle explosive power and long and strong jump results. With Fhit 9,873> Ft. 3.30. Thus the proposed work hypothesis (Ha) can be accepted. Furthermore, together the determination value of the analysis result ( $\mathrm{r} 2$ ) is equal to 0.373 . This means that the joint velocity of explosive muscle leg power as an independent variable can contribute $37.3 \%$ of the dependent variable, which is the result of the long jump. While the rest is explained by other variables. The results of the analysis can be seen in the appendix.

\section{CONCLUSION}

Based on the results of the study about the relationship of speed and explosive power of leg muscles with the results of long jumps of students in class V and VI of SD Negeri 1 Sungai Salak Indragiri Hilir Regency, it can be concluded as follows:

1. There is a significant relationship of speed with the results of the long jump as evidenced by the correlation coefficient (rxy) 0.343>rtab (0.329) with the value of tcount 2.129> t table 1.697. Furthermore, the value of determination is $11.7 \%$.

2. There is a significant relationship of leg muscle explosive power with the results of the long jump which is proven by the correlation coefficient (rxy) $0.564>$ rtab (0.329) with a tcount of 3.982> $t$ table
1.697. Furthermore, the value of determination is $31.8 \%$.

3. There is a significant relationship between the speed and explosive power of the leg muscles together with the results of the long jump as evidenced by the multiple correlation coefficient (rxy) 0.611>rtab (0.329) with a Fcount of $9,873>$ Ftable 3.30 . Furthermore, the value of determination is $37.3 \%$.

\section{REFERENCES}

[1] Eddy Purnomo dan Dapan. Dasar-dasar Gerak Atletik. Yogyakarta:Alfamedia. 2011.pp 102-103

[2] Munasifah. Atletik Cabang Lompat. Semarang. Aneka Ilmu. 2008.pp 23-26

[3] Sugiyono. Metode Penelitian Kunatitatif Kualitatif dan R\&D. Bandung Alfabeta. 2008.pp 15-19

[4] Arikunto, Suharsimi. Prosedur Penelitian Suatu Pendekatan Praktik. Jakarta Rineka Cipta. 2010.pp 44-76

[5] Ismaryati. Tes dan Pengukuran Olahraga Surakarta: Sebelas Maret University Press. Anggraeni, Adisty C. (2012). Asuhan Gizi Nutritional Care Process. Yogyakarta. 2006.pp-8892. 